"The fragments of coral belong to Stylophora palmata, Blain., a common Red Sea species; and the others to the genera Stylophora and Echinopora, but too fragmentary for specific determination.

"The beach sand has a mottled red and white appearance. The particles are nearly all rounded, and have an average diameter of 3 or 4 millimetres. They consist of corals, Echinoderms, calcareous Algæ, Gasteropod and Lamellibranch shells, and many Foraminifera. Among the latter the following could be recognized: Paneroplis fortusus, Forsk.; Orbitolites complanata, Lam.; Rotalia calcar, d'Orb.; Amphistegina lessonii, d'Orb.

"The hardened rock, "from high-water line near section 2, solid and firm in the sand and similar to the slabs of the south-east shore,' is made up of precisely the same particles as the sand above described, cemented by the infiltration of carbonate of lime among the particles. No mineral particles other than those of organic origin were observed in the sand or hardened slabs."

W. J. L. WHARTON.

\section{THE OWENS COLLEGE NATURAL HISTORY BUILDINGS.}

THE recently completed Natural History Museums and Laboratories form an important addition not merely to the Owens College itself but to the teaching appliances of the country at large.

The buildings, which, like the older part of the College, are from the plans of Mr. Alfred Waterhouse, R.A, extend along the north and east sides of the College quadrangle, the main frontage being towards the Oxford Road. They include a lofty central tower and entrance gateway, large and convenient museums for the various departments of natural history, and a very extensive and well-equipped series of laboratories for zoology, botany, geology, and mineralogy, with lecture-theatres, class-rooms, and private rooms for the professors and demonstrators. The total cost, including fittings, will not be less than $£ 80,000$.

The general appearance of the new buildings from the north-east is shown in the illustration.

The Museum block extends along the eastern or Oxford Road frontage, and is approached from the main entrance beneath the central tower; it is also in free communication with the several laboratories. It consists of two main stories, the upper of which has its floor area almost tripled by two very wide galleries, in addition to

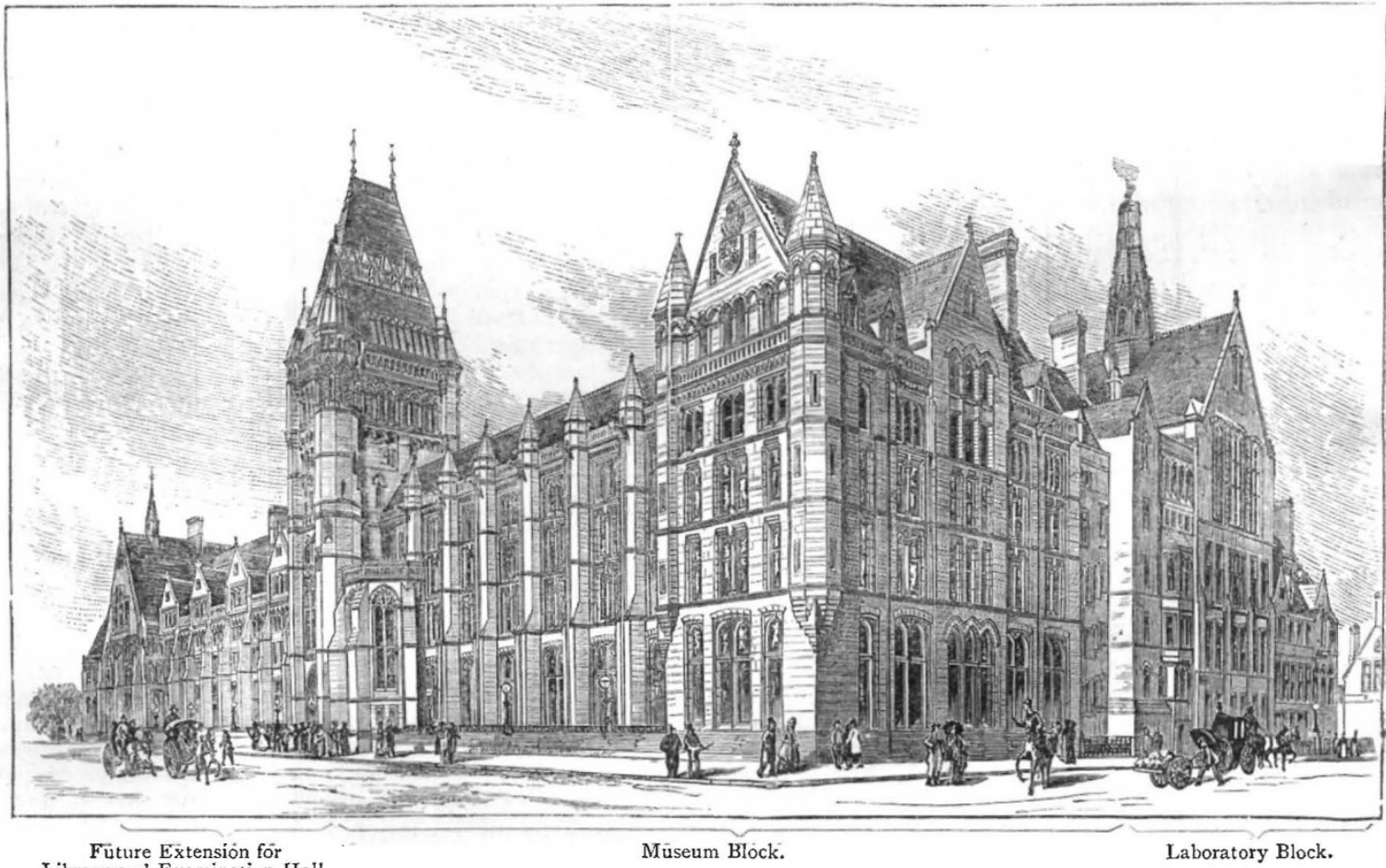

Library and Examination Hall.

View OF THE NEW BuILdings FROM THE OXFORD ROAD.

which there is very extensive storage space in the roof. The ground floor is divided into geological and mineralogical museums, measuring respectively 90 feet by 50 feet, and 65 feet by 26 feet, the former extending along the Oxford Road, the latter facing north, towards Coupland Street. These are lighted from the sides, and will be divided into bays by the main cases, which are placed at right angles to the walls, extending from them to the pillars supporting the roof. In the centre of each bay there will be a large table case, and a smaller one under the window. This arrangement gives at once a maximum of light and a maximum of what is practically wall space ; while the division into bays greatly facilitates the classifi- cation of the collections, and the different forms of case in each bay enable objects of all kinds to be displayed to advantage.

The upper museum, which is approached by a very handsome staircase in the tower, is similarly divided into zoological and botanical portions. It is lighted both from the sides and above, and the general arrangement of the cases will be the same as in the lower museum, with the addition of long rows of table cases round the edges of the galleries. Two large rooms, for use as articulating and preparation rooms, open directly on to the floor of the museurn.

Owens College already possesses very important 
natural history collections, though owing to want of space it has been impossible up to the present time to arrange or utilize them in a proper manner. The nucleus is formed by the collections previously in the possession of the Manchester Natural History and Geological Societies, which were transferred to the College in 1867 and I 869 respectively: to these, very valuable additions have since been made by gift, bequest, or purchase. The general Geological collection is a very good one ; the Tertiary collections, including those made by Prof. Boyd Dawkins and by Mr. Waters, being of exceptional importance, and the Coal Measure series being one of the best in existence. In Mineralogy the David Forbes Collection, which was purchased by the College in 1877 , is well known. In Zoology there is a good osteological series; and the collections of shells, including those presented by Mr. Cholmondeley and by Mr. Walton, and of insects are unusually complete, and in exceedingly good condition. The Botanical Museum contains a very fine British herbarium, and Prof. Williamson's unique collections illustrating the Carboniferous flora. The Museum will thus start very fairly equipped, and it may reasonably be hoped that the stimulus caused by the opening of the new buildings will lead to additional gifts and bequests, which will speedily render the collection one worthy in all respects of the College and of the city which has created it.

In the Laboratory block, which occupies the north side of the quadrangle, between the older buildings and the Musem, and is shown in the right-hand correr of the illustration, the ground floor contains on the inner side two lecture-theatres, seating 200 and 80 respectively, with convenient preparation and diagram rooms. On the other side, facing the street, are the mineralogical and petrological laboratories, geological laboratories, geological drawing room, a laboratory for applied geology, and private rooms for the professors and lecturers.

The Botanical Department is on the second floor, and comprises a large laboratory 42 feet by 28 feet, private rooms for the professor and for the demonstrator, and a dark room for physiological experiments. Provision is also made for a greenhouse 20 feet square, in direct connexion with the Laboratory.

The Zoological Laboratories occupy the third and part of the second floor.

The Junior and Senior Laboratories, which are in free communication with each other, measure 42 feet by 37 feet and 42 feet by 16 feet respectively; they are 29 feet high, and are extremely well lighted and equipped. In the Junior Laboratory the tables run north and south; each student has his own locker and drawer at his side, and gas- and water-supply in front of him; larger sinks with hot-water spirals are in the corners of the rooms; a large demonstration-table, with drawers and cupboards beneath, occupies the centre of the room ; and a lecturetable and black-board are placed against the north wall. In the Senior Laboratory the tables face north. A gallery runs along the east and west walls of the laboratories, but has not yet been fitted up.

Besides these laboratories there are a Zoological Research Laboratory 42 feet by 16 feet; private rooms for the professor and for the demonstrators; a very convenient tank-room; and large storage space.

The building has concrete floors throughout ; the heating is by hot water, and there is a very efficient system of ventilation. At each floor there is free communication between the Laboratory and Museum blocks, and the lift is placed midway between these two.

The Zoological and Botanical Laboratories have been in use since Christmas; the Museum will not be fitted up till October. An excellent opportunity for seeing the buildings is afforded by the meeting of the British Association. The ground-floor museum is being used for the reception-room and post-office, and the upper museum for reading- and writing-room, ladies' room, smokingroom, \&c. ; while the quadrangle is occupied by temporary luncheon-rooms and lavatories. The Section Rooms are partly in the College and partly in its immediate neighbourhood.

\section{THE BRITISH ASSOCIA TION.}

MANCHESTER, Tuesday Evening.

C P to the present the third Manchester meeting of the British Association promises to be as successful as everyone expected it would be. Probably no Local Committee has ever made more strenuous exertions to command success than that which for many months past has been busying itself with preparations for the present meeting. It would be difficult to suggest any improvements on the local preparations. The Reception Room in Owens College is spacious and is entirely confined to business. The Reading Rooms, Ladies' Rooms, Smoking Rooms, and Exhibition Galleries are all upstairs away from the crowd and noise. The Luncheon Rooms can accommodate hundreds, and the Sectional Rooms have had the special care of the Committee, several of whom know well the practical requirements of Sectional work. It is perhaps unfortunate that the rooms for D, E, F, and $\mathrm{G}$ are a long way from the Reception Room; but that has been unavoidable. The exhibition in the galleries of the Reading and Writing Room is of special interest. The anthropological collections contributed by Dr. Fritsch, Mr. Coutts Trotter, and others, are extensive and varied and highly instructive. Besides these there are collections of physical instruments by Sir William Thomson and Mr. W. H. Gee, and a fine series of models and apparatus for teaching practical physics in schools and colleges, exhibited by the Owens College Physical Department. In Section C, Prof. Boyd Dawkins exhibits several museum appliances, and Mr. J. H. Teall a series of specimens illustrating his paper on "The Origin of Certain Banded Gneisses." Other exhibits come under Sections D, G, and $H$, and the whole collection is likely to attract many visitors.

It is not expected that in numbers the present meeting will exceed the Newcastle meeting of 1863 , when 3335 persons were present, or even the last meeting in this city in 1861 , when the number reached 3138 . But of course at present it is impossible to say. Some weeks ago the number who had taken tickets exceeded 2000 , and to-day and to-morrow it is probable that at least another 1000 will be added. Whatever may be the number, it is certain that few past meetings of the Association will have surpassed the present in quality and weight. The marked feature is the number of foreign men of science who have promised to attend. The names of most of them have already appeared in NATURE. Their presence is entirely due to the exertions of the Local Committee, and especially, we believe, of I)r. Schuster. Nearly every man of any eminence in science abroad had a cordial letter of invitation to come to Manchester as a guest of the Local Committee, and the result is that over IOo have accepted. Among those who have arrived in Manchester to day are Prof. Riley, of Washington; Prof. Rowlands, of Baltimore ; Prof. Langley, of Michigan; Prof. Dewalque, from Belgium; and Prof. Fittica, of Marburg. Among others who are expected to-morrow I need only mention such names as those of Cleveland Abbe, Neumayer, A. C. Young, Asa Gray, Mendeléeff, Pringsheim, G. Wiedemann, Wislicenus, F. Zirkel, De Bary, Cohn, His, and the two Saportas.

Several important discussions have been arranged for. One between Sections $C$ and $D$ on the arrangement of natural history museums, will be led off by Dr. Woodward on Friday morning. There will be then other discussions in Section D on questions of the greatest scientific interest, while electrolysis will come up again, 